\title{
Inhibitory activity of Lactobacillus plantarum LMG P-26358 against Listeria innocua when used as an adjunct starter in the manufacture of cheese
}

\author{
Susan Mills ${ }^{1,3}$, L Mariela Serrano ${ }^{3}$, Carmel Griffin ${ }^{1,3}$, Paula M O'Connor ${ }^{1}$, Gwenda Schaad ${ }^{3}$, Chris Bruining ${ }^{3}$, \\ Colin Hill ${ }^{2,4}$, R Paul Ross ${ }^{1,2^{*}}$, Wilco C Meijer ${ }^{3}$
}

From 10th Symposium on Lactic Acid Bacterium

Egmond aan Zee, the Netherlands. 28 August - 1 September 2011

\begin{abstract}
Lactobacillus plantarum LMG P-26358 isolated from a soft French artisanal cheese produces a potent class lla bacteriocin with $100 \%$ homology to plantaricin 423 and bacteriocidal activity against Listeria innocua and Listeria monocytogenes. The bacteriocin was found to be highly stable at temperatures as high as $100^{\circ} \mathrm{C}$ and $\mathrm{pH}$ ranges from 1-10. While this relatively narrow spectrum bacteriocin also exhibited antimicrobial activity against species of enterococci, it did not inhibit dairy starters including lactococci and lactobacilli when tested by well diffusion assay (WDA). In order to test the suitability of Lb. plantarum LMG P-26358 as an anti-listerial adjunct with nisin-producing lactococci, laboratory-scale cheeses were manufactured. Results indicated that combining Lb. plantarum LMG P26358 (at $10^{8}$ colony forming units (cfu)/ml) with a nisin producer is an effective strategy to eliminate the biological indicator strain, L. innocua. Moreover, industrial-scale cheeses also demonstrated that Lb. plantarum LMG P-26358 was much more effective than the nisin producer alone for protection against the indicator. MALDI-TOF mass spectrometry confirmed the presence of plantaricin 423 and nisin in the appropriate cheeses over an 18 week ripening period. A spray-dried fermentate of $L b$. plantarum LMG P-26358 also demonstrated potent antilisterial activity in vitro using L. innocua. Overall, the results suggest that Lb. plantarum LMG P-26358 is a suitable adjunct for use with nisin-producing cultures to improve the safety and quality of dairy products.
\end{abstract}

\section{Introduction}

Bacteriocins are ribosomally synthesized, heat stable, antimicrobial peptides which are produced by a wide variety of bacteria. These peptides can have a narrow spectrum of inhibition (inhibiting closely related bacteria) or a broad spectrum (inhibiting a wide range of bacteria) [1]. The bacteriocins of lactic acid bacteria (LAB) have been the topic of much interest in terms of food safety due to their "generally recognised as safe" (GRAS) status [2]. They have been classified into as many as three different groups based on their biochemical and genetic properties [3]. For example, the well known bacteriocin nisin is a member of the class I group of bacteriocins.

\footnotetext{
* Correspondence: paul.ross@teagasc.ie

${ }^{1}$ Teagasc Food Research, Moorepark, Fermoy, Co. Cork, Ireland

Full list of author information is available at the end of the article
}

These peptides are also referred to as lantibiotics as they contain unusual amino acid derivatives such as lanthionine and/or $\beta$-methylanthionine as well as other posttranslational modifications. Class II contains unmodified peptides and are further subdivided into three subclasses; class IIa (one-peptide pediocin-like bacteriocins), class IIb (two-peptide bacteriocins), and class IIc (other nonpediocin-like one-peptide bacteriocins), while class III peptides consist of the thermosensitive proteins [4].

In an intensive screening program for potential antilisterial cheese starters, a potent bacteriocin producer was isolated from a French artisanal soft cheese. The producing strain was identified as Lactobacillus plantarum by $16 \mathrm{~S}$ rDNA sequencing and was later designated $L b$. plantarum LMG P-26358. The strain produces a proteinaceous compound with activity against Listeria innocua and Listeria monocytogenes. Sequence analysis indicated that
C Biomed Central

(c) 2011 Mills et al; licensee BioMed Central Ltd. This is an open access article distributed under the terms of the Creative Commons Attribution License (http://creativecommons.org/licenses/by/2.0), which permits unrestricted use, distribution, and reproduction in any medium, provided the original work is properly cited. 
the bacteriocin was a member of the class IIa group of bacteriocins, which are recognised for their potent activity against Listeria. Moreover, this group of peptides can be defined by a highly conserved charged $\mathrm{N}$-terminal domain with the consensus sequence $\mathrm{YGNGV}(\mathrm{X}) \mathrm{C}(\mathrm{X})_{4} \mathrm{C}(\mathrm{X}) \mathrm{V}(\mathrm{X})$ ${ }_{4} \mathrm{~A}$ (where $\mathrm{X}$ denotes any amino acid) and a more variable hydrophobic and/or amphiphilic C-terminal domain [3]. Structurally, these peptides contain an N-terminal $\beta$-sheet-like domain which is stabilised by a conserved disulfide bridge and a C-terminal domain consisting of one or two $\alpha$-helices, which can end with a structurally extended C-terminal tail [5]. A few class IIa bacteriocins have also been shown to contain a second disulfide bridge in the C-terminal region. This extra bridge has been associated with increased stability of the 3D structure [5-7]. Moreover, in many cases the extra disulfide bridge has been associated with greater antimicrobial potencies, especially at higher temperatures $[7,8]$.

In this study, we characterised the bacteriocin both genetically and phenotypically and assessed the in vivo performance of Lb. plantarum LMG P-26358 as an antilisterial adjunct in the presence and absence of nisinproducing starters for the manufacture of laboratory and industrial scale cheeses. As L. innocua has previously been deemed a suitable biological indicator for L. monocytogenes [9] and the strain revealed similar sensitivity to the bacteriocin as eight other $L$. monocytogenes isolates tested, it was used as a pathogen surrogate throughout the study.

\section{Materials and methods Isolation of Lactobacillus plantarum LMG P-26358 and bacteriocin assays}

Lb. plantarum LMG P-26358 was initially isolated from French artisanal cheese as follows: approximately $1 \mathrm{~g}$ of cheese was homogenized in $9 \mathrm{mls}$ of maximum recovery diluent (MRD), serially diluted and plated on MRS (de Man, Rogosa, Sharpe) agar (Difco Laboratories, Detroit, MI, USA) and grown at $30^{\circ} \mathrm{C}$ for 2-3 days. Colonies that developed were overlaid with $\sim 10 \mathrm{ml}$ of GM17 agar [M17 medium (Difco Laboratories) supplemented with $0.5 \%$ $(\mathrm{w} / \mathrm{v})$ glucose] inoculated at $0.25 \%$ with an overnight culture of L. innocua (DPC6579). The plates were incubated for another $18 \mathrm{~h}$ at $37^{\circ} \mathrm{C}$ and inspected for zones of inhibition of the overlaid culture. Colonies showing a clear zone of inhibition were sub-cultured into fresh MRS broth having first been removed from the agar overlay using a sterile scalpel blade. Pure cultures were obtained by streaking onto MRS agar. Bacteriocin assays and estimation of bacteriocin activity in activity units $(\mathrm{au}) / \mathrm{ml}$ were performed by the agar well diffusion assay (WDA) as described by Ryan et al. [10].

The sensitivity of a strain to plantaricin 423 was scored according to the diameter of the zone of inhibition surrounding the well. Each assay was performed in triplicate. Other media used in the study included BHI (BrainHeart Infusion) broth (Oxoid Ltd., Basingstoke, Hampshire, England), RCM (Re-inforced Clostridial Medium) (Merck, Darmstadt, Germany), LBS (Lactobacillus Selective) agar (Difco Laboratories), PCA (Total Plate Count) (Difco Laboratories), SLB (Sodium Lactate Broth) as described by Drinan and Cogan [11]. All strains were stocked in $50 \%$ glycerol at $-20^{\circ} \mathrm{C}$.

\section{Identification of Lactobacillus plantarum LMG P-26358}

The antimicrobial strain was identified by analyzing the $16 \mathrm{~S}$ rDNA sequence. Genomic DNA was isolated from $1.5 \mathrm{ml}$ of overnight MRS broth culture using the method of Hoffman and Winston [12] with slight modification as described by Mills et al. [13]. The $16 \mathrm{~S}$ rDNA primers CO1 (AGTTTGATCCTGGCTCAG) and CO2 (TACCTTGTTACGACTT) were used to amplify a product of $\sim 1500 \mathrm{bp}$ using an annealing temperature of $60^{\circ} \mathrm{C}$. PCR amplification was performed in a Hybaid PCR express unit (Hybaid Ltd., Middlesex, UK) according to the manufacturer's specifications using Biotaq DNA polymerase (BioTaq, Bioline Ltd., London, UK). The PCR product was purified using a Wizard SV Gel and PCR Clean-Up System (Promega, Madison, WI, USA) and sequenced with an automated DNA sequencer (Beckman Coulter Genomics, Hope End, Takeley, UK). The $16 \mathrm{~S}$ rDNA gene sequence was analysed using BLAST [14] to identify the closest bacterial neighbour.

\section{Effect of proteinase $\mathrm{K}, \mathrm{pH}$ and temperature on plantaricin 423 and stability of production}

Proteinase K sensitivity was evaluated as follows: cellfree supernatant was harvested from $1 \mathrm{ml}$ of overnight culture and exposed to a final concentration of $50 \mathrm{mg} /$ $\mathrm{ml}$ proteinase K (Sigma-Aldrich, Poole Dorset, UK) and incubated for 2 hours at $37^{\circ} \mathrm{C}$. The agar WDA was then performed against L. innocua DPC6579 with the proteinase K-treated sample and untreated cell-free supernatant as control. In order to determine the effect of $\mathrm{pH}$ on bacteriocin activity, the $\mathrm{pH}$ of cell-free supernatants was adjusted to $\mathrm{pH}$ values ranging from 1-10 using $1 \mathrm{M}$ $\mathrm{NaOH}$ or $1 \mathrm{M} \mathrm{HCl}$ and incubated for 2 hours at $25^{\circ} \mathrm{C}$ before performing the agar WDA. In a separate experiment the effect of temperature on bacteriocin activity was assessed by incubating the cell-free supernatants at $40,50,60,70,80,90$ and $100^{\circ} \mathrm{C}$ for $30 \mathrm{~min}$ after which activity was assessed against L. innocua. Stability of bacteriocin production was assessed by sub-culturing $L b$. plantarum LMG P-26358 (2\%) in MRS broth twice a day for a 10 day period and performing the agar WDA against L. innocua each day. All experiments were performed in triplicate. 


\section{HPLC purification and mass spectrometry}

The bacteriocin was purified and the molecular mass determined as follows: $50 \mu \mathrm{l}$ of stock culture was grown overnight at $37^{\circ} \mathrm{C}$ in $5 \mathrm{ml}$ of MRS broth. Forty $\mathrm{ml}$ of MRS was inoculated at $1 \%$ from the overnight culture and incubated for 6-7 hours at $37^{\circ} \mathrm{C}$ and this was then used to provide a $1 \%$ inoculum for $2 \mathrm{~L}$ of MRS broth. Following overnight incubation at $37^{\circ} \mathrm{C}$, the culture was centrifuged at $14,160 \times \mathrm{g}$ for 15 minutes and the supernatant discarded. Cells were mixed with $250 \mathrm{ml}$ of $70 \%$ isopropanol, $0.1 \%$ trifluroacetic acid (TFA) and stirred for 3 hours at room temperature. Cells were re-centrifuged and the cell-free supernatant assayed for anti-listerial activity. The isopropanol was removed from the cell-free supernatant using a Buchi rotary evaporator (Buchi, Switzerland) and the resulting prep was passed through a $5 \mathrm{~g}, 20 \mathrm{ml}$ Strata C18-E SPE column (Phenomenex, Cheshire, UK), the column was washed with $20 \mathrm{ml}$ of $30 \%$ ethanol and bacteriocin was eluted with $20 \mathrm{ml}$ of $70 \%$ isopropanol, $0.1 \%$ TFA. Isopropanol was removed from $20 \mathrm{ml}$ of the bacteriocin-containing sample and this was then applied to a C12 Proteo reverse phase HPLC column running a $25-40 \%$ acetonitrile, $0.1 \%$ TFA gradient over 35 minutes. Two HPLC runs were typically done per $2 \mathrm{~L}$ prep. Mass spectrometry was performed on the anti-listerial fractions using an Axima TOF ${ }^{2}$ MALDI TOF mass spectrometer (Shimadzu Biotech, Manchester, UK). A $0.5-\mu$ l aliquot of matrix solution (Sinapinic acid, $10 \mathrm{mg} / \mathrm{ml}$ in $50 \%$ acetonitrile- $0.1 \%(\mathrm{v} / \mathrm{v})$ TFA) was deposited onto the target and left for 5 seconds before being removed. The remaining solution was allowed air-dry and the sample solution was deposited onto the pre-coated sample spot. Matrix solution $(0.5-\mu \mathrm{l})$ was added to the deposited sample and allowed air-dry. The sample was subsequently analysed in positive-ion linear mode. The purified peptide was resuspended in $0.1 \mathrm{M}$ phosphate buffer (pH 6.8) and stored at $-20^{\circ} \mathrm{C}$. The activity in au/ml was determined by WDA as described previously [10].

\section{Identification of genes encoding plantaricin 423}

$\mathrm{N}$-terminal sequencing of the peptide was performed by Aberdeen Proteomics (Aberdeen University, Aberdeen, UK). Based on amino acid sequence similarity to plantaricin 423, primers designed to the structural gene, plaA, (423A5: AAATACTATGGTAATGGGG \& 423A3: CATG GAAAGTGCTAATTA) as described by van Reenan et al. [15] and primers designed to the whole operon in this study (423F: ATGATGAAAAAAATTGAAAAA \& 423R: CTTGATTATGAATTAACCGT) were used for PCR amplifications. DNA was amplified in a Hybaid PCR express unit. The Expand High Fidelity PCR system (Roche Diagnostics Ltd., East Sussex, UK) was used to amplify the products according to the Roche Diagnostics applications manual. The PCR product representing the whole operon was purified using the Wizard SV Gel and PCR Clean-Up System (Promega). The purified product was cloned into the TOPO XL PCR Cloning kit (Invitrogen, Paisley, UK). Clones were sequenced with an automated DNA sequencer (Beckman Coulter Genomics, UK) using the M13-Forward and Reverse priming sites on the pCR-XL-TOPO vector. Restriction enzymes were purchased from New England Biolabs (Hertfordshire, UK) and used according to manufacturer's instructions. The sequence was annotated using ORF Finder (NCBI) and analysed using BLAST [14].

\section{Mode of action of plantaricin 423}

The mode of action of plantaricin 423 against $L$. innocua was performed as described by Deraz et al. [16]. Briefly, a $1 \%$ inoculum of the culture was grown overnight. The following day the cells were harvested and resuspended in $0.1 \mathrm{M}$ potassium phosphate buffer ( $\mathrm{pH}$ 7.0). The sample was then divided into test and control and $2560 \mathrm{au} / \mathrm{ml}$ of a purified preparation of plantaricin 423 was added to the test. Both samples were incubated at $37^{\circ} \mathrm{C}$ for 8 hours. Optical density $(600 \mathrm{~nm})$ and cell numbers (colony forming units $(\mathrm{cfu} /) \mathrm{ml})$ were determined at 2 hour intervals. Each experiment was performed in triplicate and percentage killing was calculated according to the method of Deraz et al. [16] as follows:

$\%$ Killing $=[(($ initial viable cells $)-($ final viable cells $)) /$ (initial viable cells)] x 100 .

\section{Minimum inhibitory concentration (MIC) and specific activity of plantaricin 423}

The MIC was determined according to the method of Gravesen et al. [17] and Ramnath et al. [18]. Briefly, $5 \mu$ of a two-fold serial dilution of cell-free supernatant (2560 au/ $\mathrm{ml}$ plantaricin 423) or purified peptide were spotted onto GM17 plates seeded with $0.25 \%$ L. innocua. The MIC was calculated as the minimal concentration that produced a visible zone after 18 hours at $37^{\circ} \mathrm{C}$. The experiment was performed in triplicate. The specific activity was experimentally measured by generating a standard curve of bacteriocin concentration in $\mathrm{mg} / \mathrm{ml}$ versus $\mathrm{au} / \mathrm{ml}$. The experiment was performed in triplicate with two different purified preparations of plantaricin 423. In both experiments the $\mathrm{R}^{2}$ value was above the $95 \%$ confidence level.

\section{Laboratory-scale cheese manufacture with Lactobacillus plantarum LMG P-26358}

Cultures which included L. lactis DPC4268 (cheese starter), L. lactis CSK65 (nisin producer) and Lb. plantarum LMG P-26358 were inoculated into $1 \mathrm{~L}$ of whole milk heated to $32^{\circ} \mathrm{C}$ as follows: Vat $1=0.75 \%$ L. lactis DPC4268 (cheese starter); Vat $2=0.75 \%$ L. lactis DPC4268, $0.75 \%$ L. lactis CSK65 (nisin producer); Vat $3=0.75 \%$ L. lactis DPC4268, 0.75\% Lb. plantarum LMG 
P-26358; Vat $4=0.75 \%$ L. lactis DPC4268, 0.5\% Lb. plantarum LMG P-26358, 0.5\% L. lactis CSK65. A streptomycin-resistant derivative of L. innocua (DPC6578) was added to each sample vat at a level of $10^{3} \mathrm{cfu} / \mathrm{ml}$. Thirty min after inoculation Chymax rennet (Hansens, Little Island, Cork, Ireland) was added according to manufacturer's instructions and the curd was cut at the appropriate time. The temperature was then elevated from $32^{\circ} \mathrm{C}$ to $38.5^{\circ} \mathrm{C}$ over a $30 \mathrm{~min}$ period. At $\mathrm{pH} 6.2$, the whey was drained and the temperature was reduced to $32^{\circ} \mathrm{C}$. When the curd reached $\mathrm{pH} 5.2$, the curd was further drained and pressed into moulds overnight. The cheeses were then incubated at $20^{\circ} \mathrm{C}$ for 16 hours after which they were vacuum-packed and ripened at $12^{\circ} \mathrm{C}$ for 4 weeks. L. innocua DPC6578 was enumerated in each cheese on a weekly basis by homogenising $1 \mathrm{~g}$ of cheese in $2 \%$ sterile trisodium citrate and plating serial dilutions on GM17 agar containing streptomycin $(500 \mu \mathrm{g} / \mathrm{ml})$. Lb. plantarum LMG P-26358 was enumerated by plating on LBS agar. Each cheese trial was performed in triplicate.

\section{Industrial-scale Gouda cheese manufacture with Lactobacillus plantarum LMG P-26358}

The starter cultures applied in the manufacture of industrial-scale Gouda cheese were produced by CSK Food Enrichment, The Netherlands. In each vat, L. lactis CSK 976 was used as the main starter culture. The vats were set up as follows: Vat $1=$ L. lactis C976, L. lactis biovar diacetylactis $\mathrm{C} 975$ (nisin producer); Vat $2=$ L. lactis C976, Lb. plantarum LMG P-26358; Vat $3=$ L. lactis C976, L. lactis biovar diacetylactis C975, Lb. plantarum LMG P-26358; Vat $4=$ L. lactis C976, L. lactis biovar diacetylactis C975, Lb. plantarum LMG P-26358. Vat 4 differed from Vat 3 in that it contained double the amount of Lb. plantarum LMG P-26358. Gouda cheese was manufactured at the pilot plant of Nizo Food Research Ede, The Netherlands. In each experiment $1500 \mathrm{~L}$ of milk was used per vat to produce $15 \times 10 \mathrm{~kg}$ cheese wheels with $51 \%$ fat, $41 \%$ moisture and $3 \%$ salt content. The milk was bactofugated at $68^{\circ} \mathrm{C}$ for $13 \mathrm{sec}$ and pasteurized at $73^{\circ} \mathrm{C}$ for $13 \mathrm{sec}$, then the cheese milk was cooled down to $32^{\circ} \mathrm{C}$. At this point nitrate $(35 \% \mathrm{sol})$ and calcium choride (33\% sol) were added in the amounts of 55 and $70 \mathrm{~g}$, respectively, per $1500 \mathrm{~L}$. The different starter/adjunct were added as frozen pellets that resulted in bacterial counts of $10^{6}-10^{8}$ in fresh, unripened cheese. The amount of calf rennet, Ceska ${ }^{\circledR}$-Lase 150 IMCU (CSK Food Enrichment, Ede, The Netherlands) added was $20 \mathrm{~g}$ per $1500 \mathrm{~L}$ cheese milk. After a coagulation time of $35 \mathrm{~min}$, the curd was cut for $20 \mathrm{~min}$ and then $40 \%$ of the whey was removed. The remaining lactose was washed out of the curd by adding hot water. The curd was further stirred for $33 \mathrm{~min}$ at a constant temperature of $35^{\circ} \mathrm{C}$. After whey drainage, the cheese was pressed for
$90 \mathrm{~min}$ and brined for 72 hours. The $\mathrm{pH}$ of the cheeses after one day was 5.2 . The cheeses were coated with Ceska $^{\circledR}$-Coat during 18 weeks of ripening at $13^{\circ} \mathrm{C}$. Cheese samples were evaluated for bioactive properties at different stages of ripening (day 1, day 14, weeks 6, 12 and 18).

\section{Microbiological analysis of the cheese}

Samples extracted using a borer were collected in sterile bags. After discarding $1 \mathrm{~cm}$ of outer surface, the sample (app. $10 \mathrm{~g}$ ) was homogenized with a $2 \%$ sterile trisodium citrate solution at $45^{\circ} \mathrm{C}$ (1:10 dilution). The homogenized samples were diluted in physiological water, and the plate count technique was used to determine the bacterial counts. $L b$. plantarum counts were determined using commercially available MRS agar medium for selective enumeration and total lactococci counts were determined in commercially available M17 medium containing $1 \%$ lactose as the carbon source. Colonies were counted after anaerobic incubation for 3 days at $37^{\circ} \mathrm{C}$ or $30^{\circ} \mathrm{C}$ for lactobacilli or lactococci, respectively. All determinations were performed in duplicate.

The industrial cheeses were assayed for antimicrobial activity by homogenising $1 \mathrm{~g}$ of cheese in $9 \mathrm{mls}$ of MRD to which $10^{4} \mathrm{cfu} / \mathrm{ml}$ of L. innocua DPC6578 was added from an overnight culture. A control was also set up which did not contain any cheese. The cheese/Listeria slurry was then incubated at room temperature over 24 hours and Listeria counts were determined at 5 and/or 24 hours by plating serial dilutions on GM17 containing streptomycin $(500 \mu \mathrm{g} / \mathrm{ml})$. A plug of each cheese was also overlaid with L. innocua to determine if plantaricin 423 was active.

\section{Detection of nisin and plantaricin 423 in industrial cheeses by MALDI-TOF mass spectrometry}

Cheese samples were subjected to mass spectrometry to detect the presence of bacteriocins. Briefly, $20 \mathrm{ml}$ of $70 \%$ isopropanol, $0.1 \%$ TFA was added to $1 \mathrm{~g}$ of cheese sample and mixed at room temperature for 3-4 hours. Cheese mixtures were centrifuged and $20 \mathrm{ml}$ of $70 \%$ isopropanol, $0.1 \%$ TFA was added to the supernatant. The isopropanol was removed using rotary evaporation and suspensions were re-centrifuged to spin down particulate matter. The $\mathrm{pH}$ of the supernatant was adjusted to 4-5 by adding approximately $30 \mu \mathrm{l}$ of $7.5 \mathrm{~N} \mathrm{NaOH}$ and then passed through a 5 g $20 \mathrm{ml}$ Phenomenex Strata C18-E SPE column, columns were washed with $20 \%$ ethanol and bacteriocins eluted with $70 \%$ isopropanol, $0.1 \%$ TFA. The isopropanol was removed from the 70\% isopropanol, $0.1 \%$ TFA samples before applying to a semi prep C12 Proteo Jupiter RP-HPLC column running a $25-48 \%$ acetonitrile, $0.1 \%$ TFA gradient over 35 minutes. Eluent was monitored via UV at $214 \mathrm{~nm}$. Fractions were collected at $1 \mathrm{~min}$ intervals and nisin- and plantaricin-containing fractions were 
analysed by MALDI-TOF mass spectrometry as previously described to confirm their presence.

\section{Spray-drying}

A spray-dried powder of $L b$. plantarum LMG P-26358 was generated by growing the strain to $8 \mathrm{~L}$ in $20 \% \mathrm{RSM}$ with $0.5 \%$ yeast extract and $0.2 \mathrm{~g} / \mathrm{l} \mathrm{MnSO}_{4} \cdot 4 \mathrm{H}_{2} \mathrm{O}$. The fermentate was concentrated to $40 \%$ total solids in a singleeffect falling-film evaporator (Anhydro F1-Lab) before spray-drying. Concentrates were then dehydrated in a pilot-scale Anhydro spray drier (Model Lab 3) at an inlet temperature of $187^{\circ} \mathrm{C}$ and an air outlet temperature of $\sim 85^{\circ} \mathrm{C}$. The powder was assayed for viable cells by plating on PCA and LBS, and counts were compared across both sets of plates to determine the $\mathrm{cfu} / \mathrm{g}$ of $L b$. plantarum LMG P-26358. Anti-listerial activity was assessed by adding the powder at $1 \%(\mathrm{w} / \mathrm{v}), 5 \%(\mathrm{w} / \mathrm{v}), 10 \%(\mathrm{w} / \mathrm{v})$ and $15 \%$ (w/v) to $10^{4} \mathrm{cfu} / \mathrm{ml}$ of L. innocua DPC6578 in GM17 broth. The culture/powder mix was incubated for 6 hours at $37^{\circ} \mathrm{C}$ and samples were removed every 2 hours to enumerate Listeria by selecting on GM17 with streptomycin $(500 \mu \mathrm{g} / \mathrm{ml})$. Each experiment was performed in triplicate.

\section{Results \\ Isolation and identification of Lactobacillus plantarum LMG P-26358}

Lb. plantarum was isolated from a soft French artisanal cheese due to its associated production of a large zone from the colony when overlaid with L. innocua. Following purification it was later identified as $L b$. plantarum by $16 \mathrm{~S}$ rDNA sequencing and designated $L b$. plantarum LMG P-26358. To determine if the inhibitory activity was proteinaceous, the supernatant was treated with proteinase $\mathrm{K}$ and tested against L. innocua by WDA. The loss of activity confirmed that the antimicrobial substance produced by $L b$. plantarum was indeed proteinaceous. The level of inhibitory activity in culture supernatant against $L$. innocua was determined to be $2560 \mathrm{au} / \mathrm{ml}(\sim 7$ $8 \mathrm{~mm}$ zone) when measured by WDA. Sugar acidification profiles indicated that $L b$. plantarum LMG P-26358 can grow efficiently on both glucose and lactose with generation times (GTs) of 100 mins and specific growth rates of 0.1814 and 0.1815 , respectively. Maltose was the most efficient sugar for growth with a GT of 79 mins and specific growth rate of 0.2277 , while the strain was unable to metabolise raffinose.

\section{Identification of the antimicrobial substance produced by Lactobacillus plantarum LMG P-26358 and characterisation of the genetic machinery}

The antimicrobial substance was purified by HPLC and the molecular mass was determined to be $3929 \mathrm{Da}$ using MALDI-TOF mass spectrometry. The peptide was then partially sequenced revealing the first 10 amino acids. These 10 amino acids were found to be identical to the class IIa bacteriocin plantaricin 423 which is produced by $L b$. plantarum 423 and has a molecular mass of 3932.74 [15]. Based on the sequence of plantaricin 423 of $\mathrm{Lb}$. plantarum 423 primers were generated to the bacteriocin structural gene and to the complete operon involved in the production of the bacteriocin. Both sets of primers generated PCR products of the correct size for the structural gene (150 bps) and the operon ( 3582 bps) from $L b$. plantarum LMG P-26358. DNA sequence analysis and annotation of the amplified operon revealed that the structural gene is identical to that of plantaricin 423 from $L b$. plantarum 423. While 17 base pair differences were observed across the remainder of the operon, such changes could be considered silent in the majority of cases. The bacteriocin produced by $L b$. plantarum LMG P-26358 was designated plantaricin 423.

\section{Effect of heat and pH on the activity of plantaricin 423 and stability of bacteriocin production by Lactobacillus plantarum LMG P-26358 over a 10 day period}

Heat treatment of the bacteriocin at 40, 50, 60, 70, 80, 90 and $100^{\circ} \mathrm{C}$ for 30 minutes did not compromise its antimicrobial activity. Likewise, the activity of the bacteriocin was unaffected by $\mathrm{pH}$ as the bacteriocin continued to produce $2560 \mathrm{au} / \mathrm{ml}$ following incubation of the supernatant at $\mathrm{pH}$ values from $1-10$ for 2 hours at $25^{\circ} \mathrm{C}$. The producing strain, $\mathrm{Lb}$ plantarum LMG P-26358, was sub-cultured for 10 days and the supernatant was assayed for activity each day. The strain continued to produce equivalent potent activity against L. innocua on each day of the 10-day period.

\section{Spectrum of inhibition}

The activity of plantaricin 423 was assayed against 34 indicator strains which included LAB starters such as L. lactis and Lactobacillus species as well as food spoilage and pathogenic bacteria such as Bacillus subtilis and Salmonella typhi and eight isolates of L. monocytogenes, six of which were previously isolated from smear-ripened cheeses and cheese plants. Apart from the expected inhibitory activity against Listeria, plantaricin 423 also inhibited Enterococcus faecalis, producing a $5 \mathrm{~mm}$ zone, and Enterococcus faecium, producing a $2 \mathrm{~mm}$ zone. The lack of inhibition against the starters tested in the study suggests that Lb. plantarum LMG P-26358 is a suitable adjunct for cheese manufacture.

\section{Mode of action of plantaricin 423}

The effect of plantaricin 423 on Listeria was investigated to determine if it has a bactericidal or bacteriostatic mode of action. The purified peptide (resuspended in phosphate buffer) with an initial activity of $102,400 \mathrm{au} / \mathrm{ml}$ was added to cell suspensions at a final concentration of 
$2560 \mathrm{au} / \mathrm{ml}$ and growth was assessed by measuring the optical density and cell numbers over an eight hour period, and percentage killing was also calculated. Over the eight hour period, a marked decrease was observed in both optical density and cell viability for samples containing plantaricin 423, compared to controls (Figure 1). A three log reduction was recorded for cells in the presence of bacteriocin within the first 2 hours, corresponding to 99.9\% killing and a 2 log reduction was observed after the eighth hour (99\% killing). The dramatic decrease in optical density indicates that plantaricin 423 has a bactericidal effect on cells of L. innocua (Figure 1).

\section{Minimum inhibitory concentration and specific activity of} plantaricin $\mathbf{4 2 3}$

The minimum inhibitory concentration (MIC) against L. innocua and eight isolates of L. monocytogenes was estimated to be $40 \mathrm{au} / \mathrm{ml}$ using purified plantaricin 423 or cell-free supernatant (Figure 2). A standard curve was generated to determine specific activity. The activity in $\mathrm{mg} / \mathrm{ml}$ can thus be calculated using the equation $y=10^{-5}(X)$ where $X$ is the activity expressed as au/ml and $\mathrm{y}$ is the activity expressed as $\mathrm{mg} / \mathrm{ml}$. Therefore, the MIC which was determined to be $40 \mathrm{au} / \mathrm{ml}$ is equivalent to $0.4 \mu \mathrm{g} / \mathrm{ml}(0.10173 \mu \mathrm{M})$.

\section{Laboratory-scale cheese production using Lactobacillus plantarum LMG P-26358 as an adjunct culture}

Lb. plantarum LMG P-26358 was found to grow adequately in $10 \%$ RSM substituted with $0.1 \%$ yeast extract. Supplementation of the starter culture medium with 0.2 g/l $\mathrm{MnSO}_{4} \cdot 4 \mathrm{H}_{2} \mathrm{O}$ was also shown to facilitate its growth. Combining the strain with the nisin producer $L$. lactis CSK 65 (produces $320 \mathrm{au} / \mathrm{ml}$ of nisin) eliminated the requirement for yeast extract in 10\% RSM and the strain continued to produce a full zone of inhibition against L. innocua following overnight growth, although acidification and growth of $L b$. plantarum LMG P-26358 was impeded in the presence of nisin in the first eight hours of growth. Studies suggested that at least $10^{8} \mathrm{cfu} / \mathrm{ml}$ of Lb. plantarum LMG P-26358 were required for optimal bacteriocin production. Laboratory-scale cheese spiked with $10^{3} \mathrm{cfu} / \mathrm{ml}$ of L. innocua was manufactured to test the anti-listerial capacity of $L b$. plantarum LMG P26358 in the presence and absence of the nisin producer L. lactis CSK65.

Each cheese was ripened at $12^{\circ} \mathrm{C}$ for 4 weeks and $\mathrm{Lis}$ teria and Lb. plantarum LMG P-26358 was enumerated each week of the ripening period (Figure 3 ). On day 28, a plug of each cheese was also overlaid with $L$. innocua to determine if the bacteriocin was still active. By day 28 , L. innocua numbers were dramatically reduced in Vat 3 (Lb. plantarum LMG P-26358) as compared to Vats 1 and 2 and Listeria was not detected in Vat 4 ( Lb. plantarum LMG P-26358 and nisin producer) suggesting that the combination of plantaricin 423 and nisin was more effective than plantaricin 423 alone. On days 1 and 28 after cheese manufacture $L b$. plantarum LMG P-26358 was present at $10^{8} \mathrm{cfu} / \mathrm{ml}$ or more. Overlays of cheese plugs on day 28 indicated that the Lb. plantarum LMG P-26358-containing cheeses produced a zone against L. innocua (Figure 3).

\section{Industrial-scale Gouda cheese production using Lactobacillus plantarum LMG P-26358 culture}

Industrial-scale Gouda cheese was manufactured at CSK Food Enrichment, The Netherlands. The cheeses were tested over an 18 week period for anti-listerial activity (a)

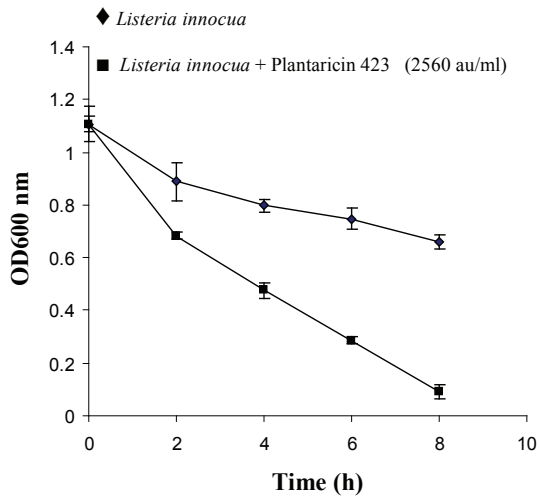

(b)

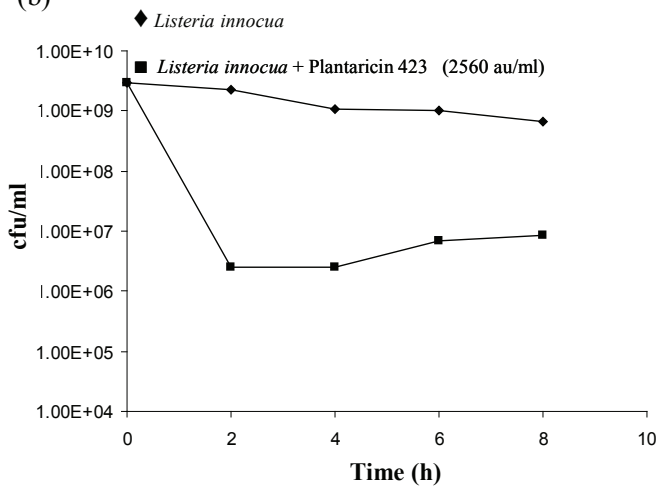

Figure 1 Mode of action of plantaricin 423 on Listeria innocua. Parameters tested were optical density (OD $600 \mathrm{~nm}$ ) (a) and cell viability $(\mathrm{cfu} / \mathrm{ml})(\mathrm{b})$ 


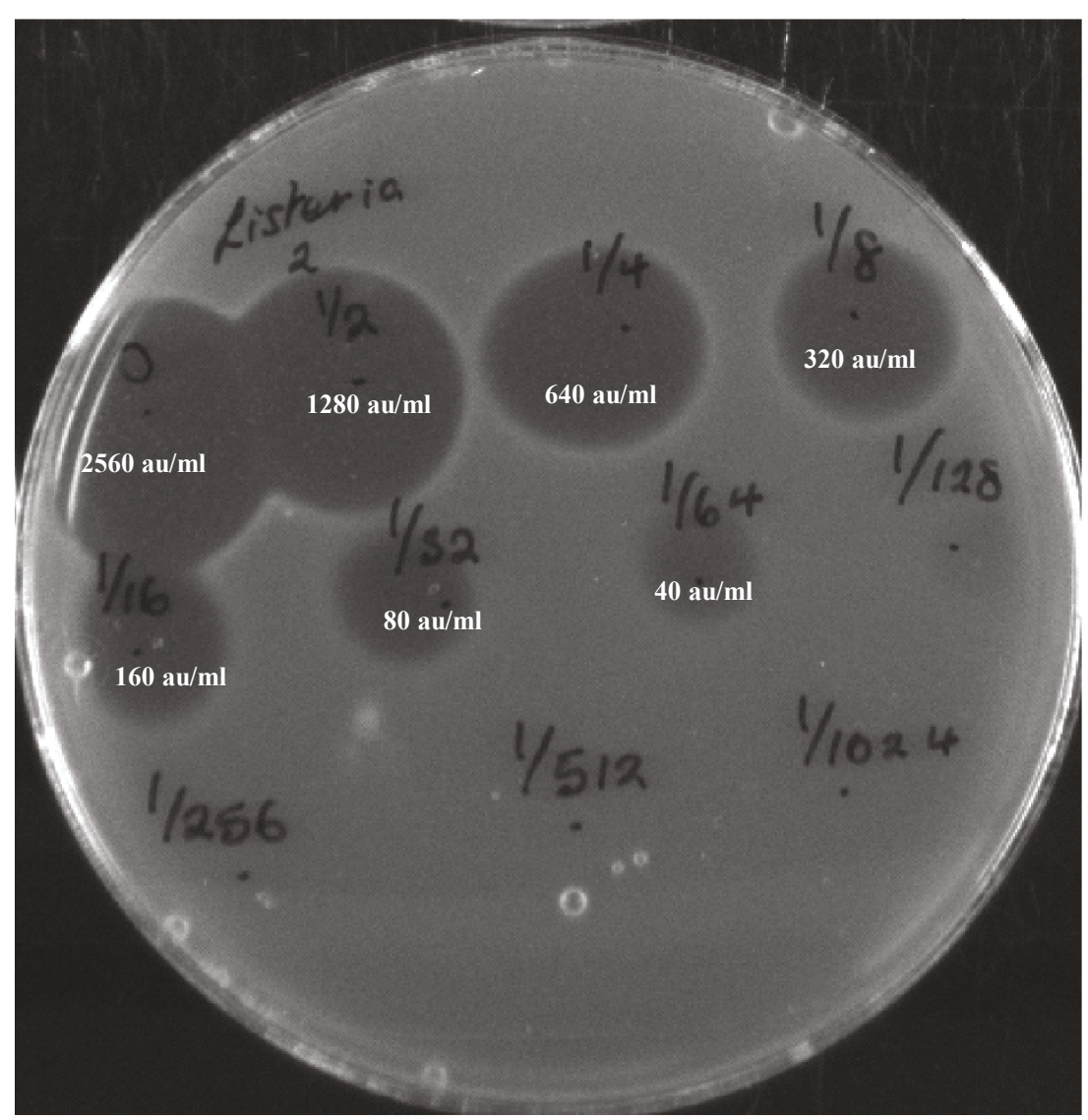

Figure 2 Minimum inhibitory concentration of plantaricin 423 against Listeria innocua defined as the minimal concentration showing a visible zone of inhibition.

by generating cheese/Listeria slurries in MRD. The cheeses produced with $L b$. plantarum LMG P-26358 were much more effective at controlling Listeria numbers than using the nisin producer alone (Figure 4). A slight antagonistic effect may have occurred between the nisin producer and $L b$. plantarum LMG P-26358 as zones from cheese plugs of Vats 3 and 4 were always slightly smaller than zones from Vat 2 (results not shown). We have already observed that nisin does slow the growth of Lb. plantarum LMG P-26358 in the initial stages of growth. However, Listeria counts did not vary greatly between Vats 2, 3 and 4. Nisin and Plantaricin 423 were both detected in the appropriate cheeses by mass spectrometry over the 18 week ripening period (results not shown).

\section{Frequency of bacteriocin resistance development in Listeria innocua}

The frequency of resistance development in L. innocua to $2560 \mathrm{au} / \mathrm{ml}$ plantaricin 423 (purified preparation) was calculated at $1.13 \times 10^{-3}$. However, the frequency of resistance development against $320 \mathrm{au} / \mathrm{ml}$ nisin was lower at $2.16 \times 10^{-2}$. Simultaneous exposure to plantaricin 423 and nisin at the above levels reduced the frequency of resistance development to $1.34 \times 10^{-4}$. The resistant colonies were removed and tested for their sensitivity to plantaricin 423. However, all bacteriocin resistant strains (including nisin resistant and plantaricin 423 resistant) remained sensitive to $2560 \mathrm{au} / \mathrm{ml}$ suggesting that the cells were 'tolerant' rather than completely resistant. We did however isolate plantaricin 423 resistant derivatives of L. innocua by growing approximately $10^{8}$ exponential phase cells $/ \mathrm{ml}$ overnight in the presence of a purified preparation of plantaricin $423(2560 \mathrm{au} / \mathrm{ml})$ in broth.

\section{Antimicrobial activity of spray-dried powder of $L b$. plantarum LMG P-26358}

Preliminary results demonstrated that $L b$. plantarum LMG P-26358 was suitable for spray-drying and the resulting powder was capable of inhibiting $L$. innocua in vitro demonstrating an avenue worthy of further investigation considering the wide range of applications for antimicrobial powders. A total of $8 \mathrm{~L}$ of an overnight fermentate 


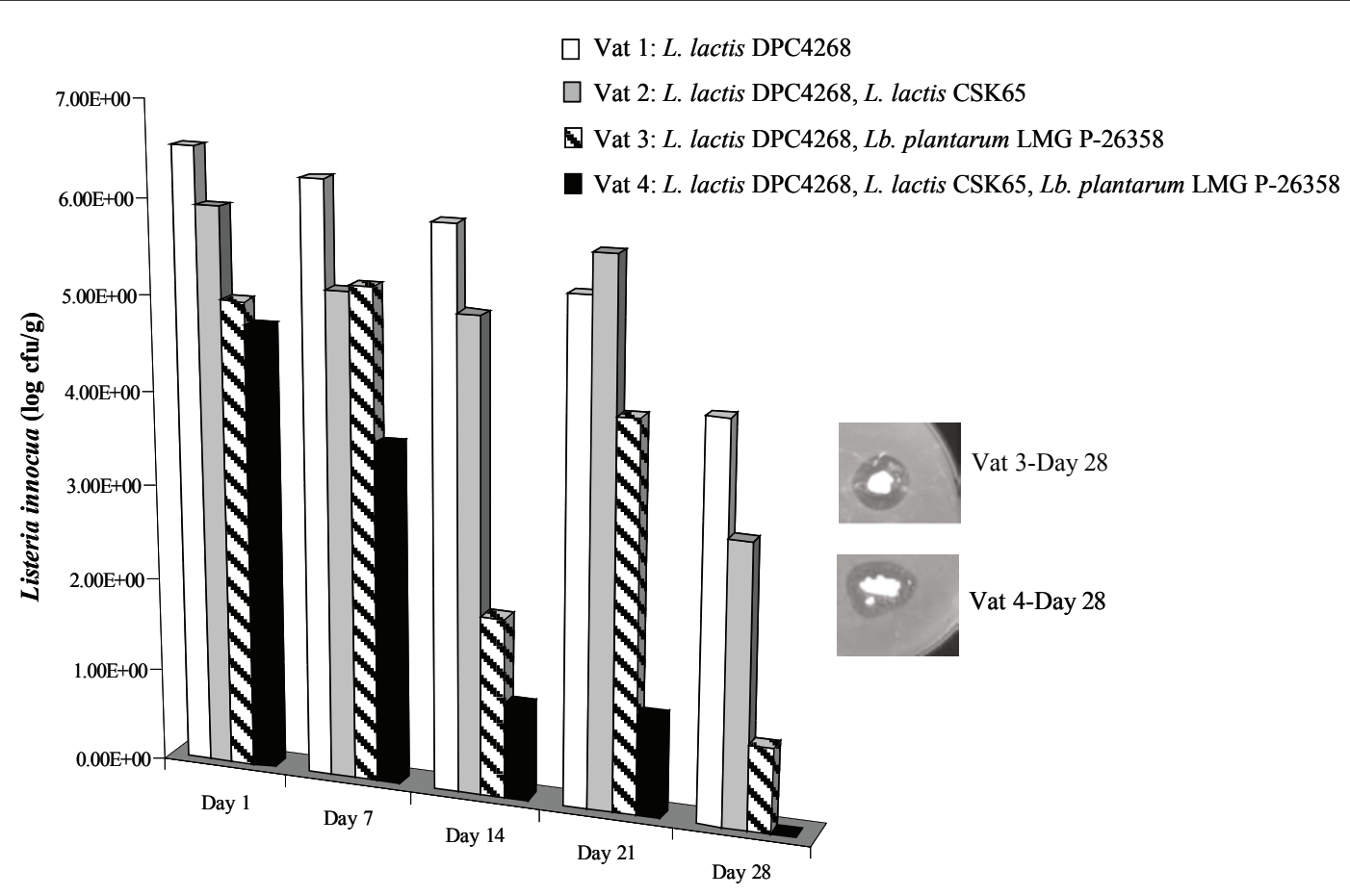

Figure 3 Counts of viable Listeria innocua cells in cheeses manufactured with the starter Lactococcus lactis DPC4268 (Vat 1) and accompanied with either Lactococcus lactis CSK 65 (Vat 2); Lactobacillus plantarum LMG P-26358 (Vat 3); Lactococcus lactis CSK 65 and Lactobacillus plantarum LMG P-26358 (Vat 4). Insert shows cheeses (day 28) from vats 3 and 4 overlaid with Listeria innocua.

of $L b$. plantarum LMG P-26358 was spray-dried, yielding approximately $1 \mathrm{~kg}$ of powder containing $6.0 \times 10^{4}$ viable $\mathrm{cfu} / \mathrm{g}$ of $\mathrm{Lb}$. plantarum LMG P-26358. The powder was tested against $L$. innocua at concentrations of $1,5,10$ and $15 \%$. All concentrations tested exhibited antimicrobial activity against the indicator strain (Figure 5). Indeed, at $15 \%$ the powder reduced L. innocua numbers by approximately 4 logs within 6 hours when compared with the control.

\section{Discussion}

Lb. plantarum LMG P-26358 was isolated from a soft French artisanal cheese because of its ability to produce a bacteriocin against L. innocua. The bacteriocin structural peptide was found to be identical to the class IIa bacteriocin plantaricin 423 produced by $L b$. plantarum 423, a strain previously isolated from sorghum beer by van Reenan et al. [19] although seventeen base pair differences were observed across the remainder of the operon. Plantaricin 423 produced by Lb. plantarum LMG P-26358 was found to have a bactericidal effect on L. innocua growth with a MIC of $40 \mathrm{au} / \mathrm{ml}$, a MIC that was also observed against eight $L$. monocytogenes isolates. However, initial results suggested that at least $10^{8}$ cells of $L b$. plantarum LMG P-26358 are required for optimal activity of the bacteriocin against Listeria. The bacteriocin was also found to inhibit enterococcal strains including E. faecium and E. faecalis. Dairy starters including $L$. lactis and various lactobacilli were insensitive to the bacteriocin.

Resistance development in Listeria to class IIa bacteriocins is a well recognised phenomenon and is associated with the mannose phosphotransferase system, the receptor for class IIa bacteriocins in Listeria[20-22]. We observed that L. innocua developed resistance to plantaricin $423(2560 \mathrm{au} / \mathrm{ml})$ at a frequency of $10^{-3}$, and to nisin $(320 \mathrm{au} / \mathrm{ml})$ at a frequency of $10^{-2}$. When both nisin and plantaricin 423 were combined at the same concentrations the frequency of resistance development was reduced to $10^{-4}$. However, these experiments were performed using purified preparations of plantaricin 423 and nisin and the optimal conditions for Listeria growth. In the complex environment of cheese, the level of resistance development may be dramatically hindered by numerous hurdles including salt, temperature etc.

Considering that bacteriocins can be extremely effective for food safety applications when used in combination with other hurdles as reviewed by Mills et al. [23] we evaluated the suitability of $L b$. plantarum LMG P26358 for use as an adjunct culture in cheese manufacture in terms of its anti-listerial capacity in conjunction with a nisin producer. The combination of nisin- and 

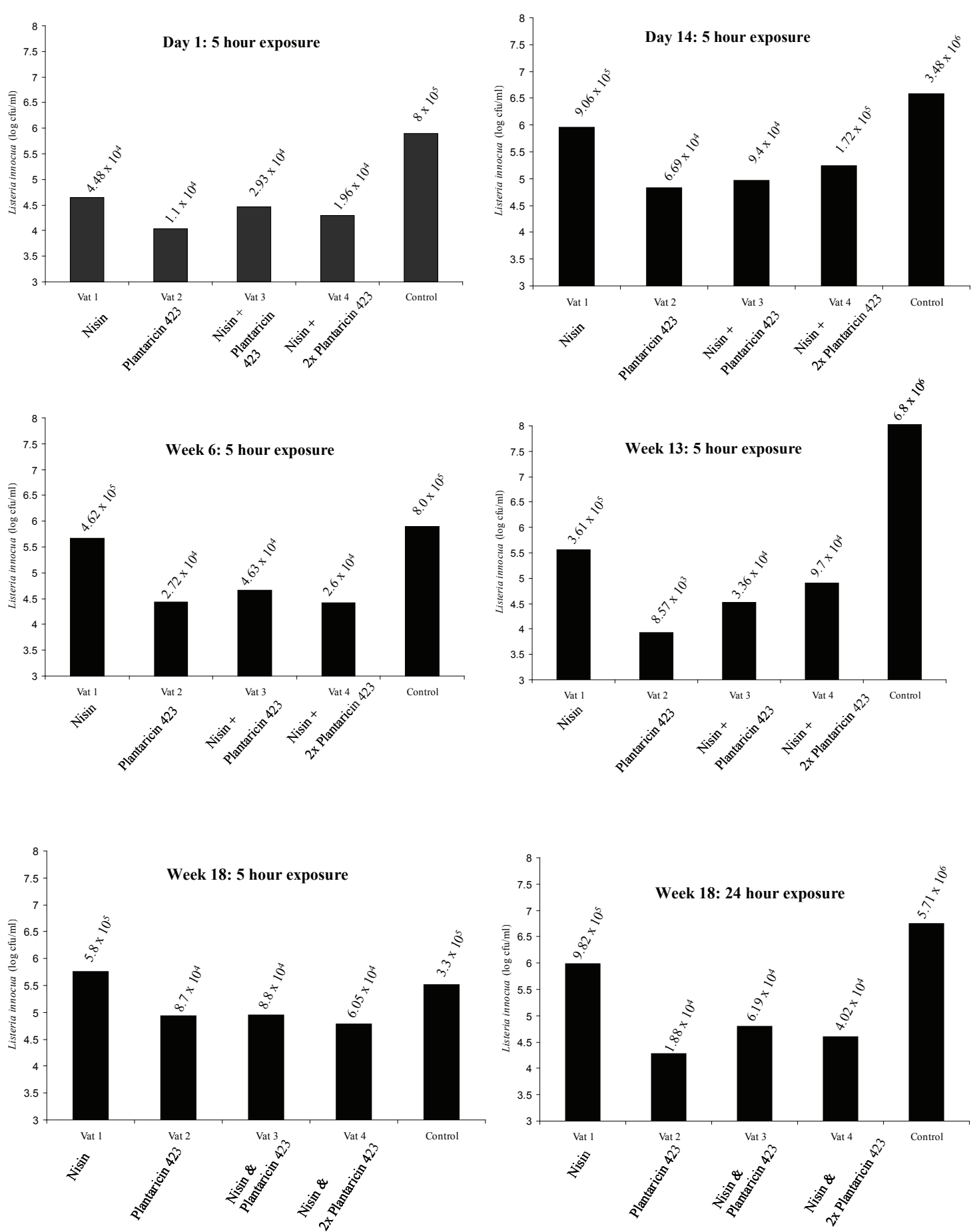

Figure 4 Listeria innocua counts following 5 or 24 hours of exposure to $1 \mathrm{~g}$ of industrial cheeses.

plantaricin- CSK producing cultures in laboratory cheeses (deliberately spiked with $L$. innocua) was found to dramatically reduce Listeria numbers. Indeed, by day 28 of ripening, the cheese manufactured with the nisin producer and $L b$. plantarum LMG P-26358 had no viable Listeria cells, suggesting that the emergence of resistant mutants was not an issue in the cheese environment. Moreover, a plug of the cheese itself $(<1 \mathrm{~g})$ 


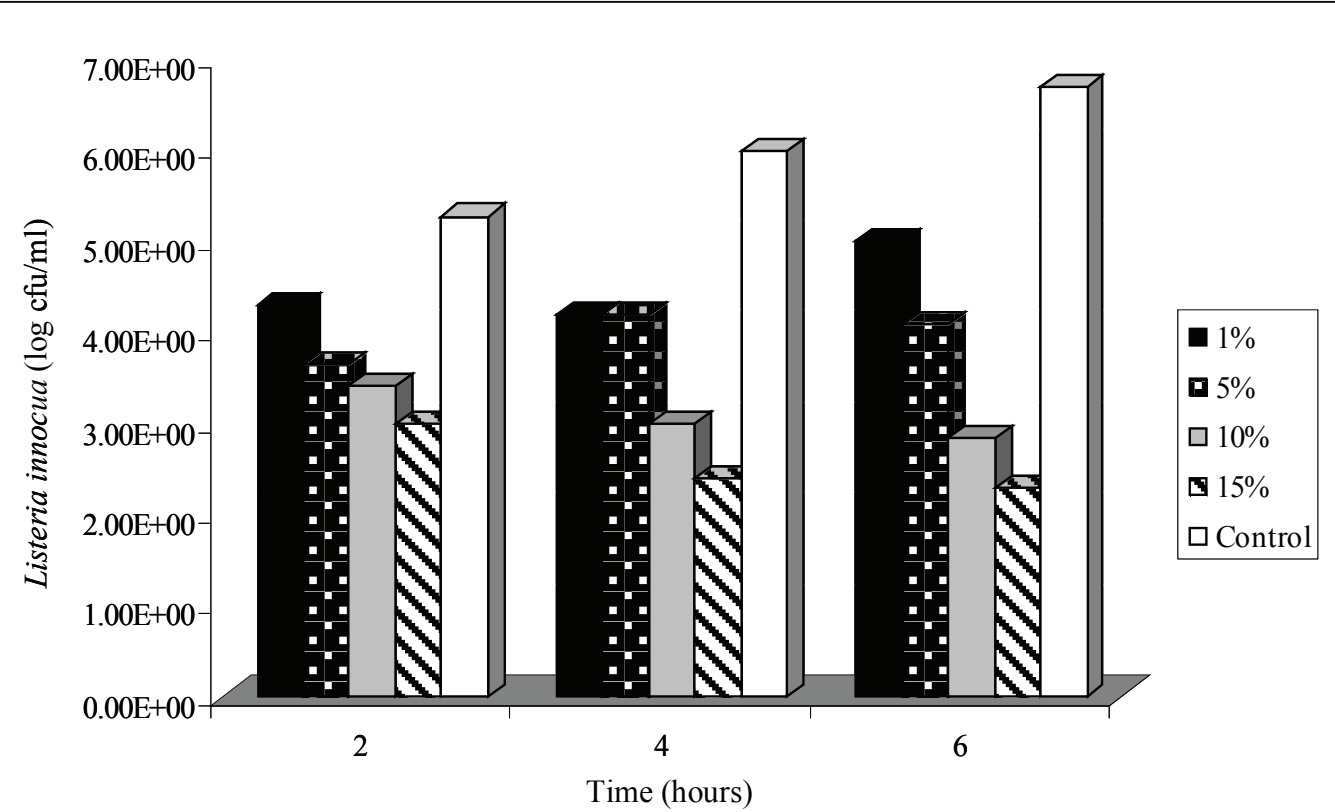

Figure 5 The effect of Lactobacillus plantarum LMG P-26358 spray-dried powder (1, 5, 10 and 15\%) on the viability of Listeria innocua.

from day 28 of ripening produced a zone of inhibition against $L$. innocua. Importantly, $L b$. plantarum numbers reached $10^{8} \mathrm{cfu} / \mathrm{ml}$ on the first day of cheese manufacture and existed at $10^{9} \mathrm{cfu} / \mathrm{ml}$ by day 28 . Anti-listerial capacity was evaluated for industrial cheeses by adding $1 \mathrm{~g}$ of the cheese to L. innocua cells. The cheese slurry behaved as an anti-listerial ingredient and was shown to prevent the proliferation of L. innocua. Overall, the synergistic effect observed in nisin- and plantaricin 423containing laboratory cheeses was not observed for the industrial-scale cheeses. However, this may be a reflection of the method of analysis which differed between both industrial and laboratory-scale cheeses. We could deduce that $L b$. plantarum LMG P-26358 was much more effective at inhibiting Listeria than the nisin producer alone. Moreover, mass spectrometry confirmed the presence of nisin and plantaricin 423 in the appropriate cheeses over an 18 week period suggesting that the integrity of each bacteriocin remains intact in the complex cheese environment. Cheese plugs from the industrial cheeses containing $L b$. plantarum LMG P26358 continued to produce a zone of inhibition against L. innocua over the ripening period also.

A spray-dried powder was then generated from the fermentate of $L b$. plantarum LMG P-26358. Preliminary results suggested that the powder exhibited significant anti-listerial activity during in vitro assays suggesting that such a bioactive ingredient could have beneficial applications as a food-safety ingredient in various dairy products including yogurts, cheeses and coatings.
In conclusion, we have demonstrated that $L b$. plantarum LMG P-26358 isolated from a soft French artisanal cheese has potential as an anti-listerial adjunct starter in the manufacture of cheese using the biological indicator strain L. innocua. Moreover, the strain is compatible with nisin producers and dramatically increases the potency of nisin. However, although class IIa bacteriocins are renowned for their anti-listerial activity, the strain should be tested against a wide range of L. monocytogenes strains if it is to be used in food safety applications, preferably isolated from different regions. In addition, we have observed that the strain's anti-listerial activity is less effective at levels $\leq 10^{7}$ cells $/ \mathrm{ml}$. Therefore, to ensure optimal protection we suggest that $L b$. plantarum LMG P-26358 be used as an adjunct starter with nisin producers at levels of $10^{8} \mathrm{cell} / \mathrm{ml}$ or greater to improve the quality and safety of cheese products.

\section{Acknowledgements}

This article has been published as part of Microbial Cell Factories Volume 10 Supplement 1, 2011: Proceedings of the 10th Symposium on Lactic Acid Bacterium. The full contents of the supplement are available online at http:// www.microbialcellfactories.com/supplements/10/S1.

\section{Author details}

${ }^{1}$ Teagasc Food Research, Moorepark, Fermoy, Co. Cork, Ireland. ${ }^{2}$ Alimentary Pharmabiotic Centre, Cork, Ireland. ${ }^{3}$ CSK Food Enrichment, Ede, The Netherlands. ${ }^{4}$ Department of Microbiology, University College Cork, Ireland.

\section{Competing interests}

The authors declare that they have no competing interests.

Published: 30 August 2011 
References

1. Cotter PD, Hill C, Ross RP: Bacteriocins: developing innate immunity for food. Nat Rev Microbiol 2005, 3.777-788.

2. Settanni L, Corsetti A: Application of bacteriocins in vegetable food preservation. Int J Food Microbiol 2008, 121:123-138.

3. Drider D, Fimland G, Hechard Y, McMullen LM, Prevost $H$ : The continuing story of class Ila bacteriocins. Microbiol Mol Biol Rev 2006, 70:564-582.

4. Klaenhammer TR: Genetics of bacteriocins produced by lactic acid bacteria. FEMS Microbiol Rev 1993, 12:39-85.

5. Fimland G, Johnsen L, Dalhus B, Nissen-Meyer J: Pediocin-like antimicrobial peptides (class lla bacteriocins) and their immunity proteins: biosynthesis, structure, and mode of action. J Pept Sci 2005, 11:688-696.

6. Uteng M, Hauge HH, Markwick PR, Fimland G, Mantzilas D, Nissen-Meyer J, Muhle-Goll C: Three-dimensional structure in lipid micelles of the pediocin-like antimicrobial peptide sakacin $\mathrm{P}$ and a sakacin $\mathrm{P}$ variant that is structurally stabilized by an inserted C-terminal disulfide bridge. Biochemistry 2003, 42:11417-11426.

7. Fimland $G$, Johnsen L, Axelsson L, Brurberg MB, Nes IF, Eijsink VG, NissenMeyer J: A C-terminal disulfide bridge in pediocin-like bacteriocins renders bacteriocin activity less temperature dependent and is a major determinant of the antimicrobial spectrum. J Bacteriol 2000, 182:2643-2648

8. Eijsink VG, Skeie M, Middelhoven PH, Brurberg MB, Nes IF: Comparative studies of class lla bacteriocins of lactic acid bacteria. Appl Environ Microbiol 1998, 64:3275-3281.

9. Kamat AS, Nair PM: Identification of Listeria innocua as a biological indicator for inactivation of $L$. monocytogenes by some meat processing treatments. Lebensmittel-Wissenschaft und-Technologie-Food Sci Technol 1996, 29:714-720.

10. Ryan MP, Rea MC, Hill C, Ross RP: An application in cheddar cheese manufacture for a strain of Lactococcus lactis producing a novel broadspectrum bacteriocin, lacticin 3147. Appl Environ Microbiol 1996, 62:612-619.

11. Drinan FD, Cogan TM: Detection of propionic acid bacteria in cheese J Dairy Res 1992, 59:65-69.

12. Hoffman CS, Winston F: A ten-minute DNA preparation from yeast efficiently releases autonomous plasmids for transformation of Escherichia coli. Gene 1987, 57:267-272.

13. Mills S, Griffin C, Coffey A, Meijer WC, Hafkamp B, Ross RP: CRISPR analysis of bacteriophage insensitive mutants (BIMs) of industrial Streptococcus thermophilus - implications for starter design. J Appl Microbiol 2010, 108:945-955.

14. Altschul SF, Madden TL, Schaffer AA, Zhang J, Zhang Z, Miller W, Lipman DJ: Gapped BLAST and PSI-BLAST: a new generation of protein database search programs. Nucleic Acids Res 1997, 25:3389-3402.

15. Van Reenen CA, Chikindas ML, Van Zyl WH, Dicks LM: Characterization and heterologous expression of a class lla bacteriocin, plantaricin 423 from Lactobacillus plantarum 423, in Saccharomyces cerevisiae. Int J Food Microbiol 2003, 81:29-40.

16. Deraz SF, Karlsson EN, Khalil AA, Mattiasson B: Mode of action of acidocin D20079, a bacteriocin produced by the potential probiotic strain, Lactobacillus acidophilus DSM 20079. J Ind Microbiol Biotechnol 2007 34:373-379.

17. Gravesen A, Ramnath $M$, Rechinger KB, Andersen N, Jansch L, Hechard $Y$, Hastings JW, Knochel S: High-level resistance to class lla bacteriocins is associated with one general mechanism in Listeria monocytogenes. Microbiology 2002, 148:2361-2369.

18. Ramnath M, Beukes M, Tamura K, Hastings JW: Absence of a putative mannose-specific phosphotransferase system enzyme IIAB component in a leucocin A-resistant strain of Listeria monocytogenes, as shown by two-dimensional sodium dodecyl sulfate-polyacrylamide gel electrophoresis. Appl Environ Microbiol 2000, 66:3098-3101.

19. van Reenen CA, Dicks LM, Chikindas ML: Isolation, purification and partial characterization of plantaricin 423 , a bacteriocin produced by Lactobacillus plantarum. J Appl Microbiol 1998, 84:1131-1137.

20. Vu-Khac H, Miller KW: Regulation of mannose phosphotransferase system permease and virulence gene expression in Listeria monocytogenes by the $\mathrm{Ell}_{\mathrm{t}}^{\mathrm{Man}}$ transporter. Appl Environ Microbiol 2009, 75:6671-6678.

21. Arous $S$, Dalet $K$, Hechard $Y$ : Involvement of the mpo operon in resistance to class Ila bacteriocins in Listeria monocytogenes. FEMS Microbiol Lett 2004, 238:37-41
22. Kjos M, Salehian Z, Nes IF, Diep DB: An extracellular loop of the mannose phosphotransferase system component IIC is responsible for specific targeting by class Ila bacteriocins. J Bacterio/ 2010, 192:5906-5913.

23. Mills S, Stanton C, Hill C, Ross RP: New developments and applications of bacteriocins and peptides in foods. Ann Rev Food Sci Technol 2011 2:299-329.

doi:10.1186/1475-2859-10-S1-S7

Cite this article as: Mills et al:: Inhibitory activity of Lactobacillus plantarum LMG P-26358 against Listeria innocua when used as an adjunct starter in the manufacture of cheese. Microbial Cell Factories 2011 10(Suppl 1):S7.

\section{Submit your next manuscript to BioMed Central and take full advantage of:}

- Convenient online submission

- Thorough peer review

- No space constraints or color figure charges

- Immediate publication on acceptance

- Inclusion in PubMed, CAS, Scopus and Google Scholar

- Research which is freely available for redistribution
C) Biomed Central 